\title{
Neg-raising, IP-Internal Topic and Focus Phrases and the Structure of the Awing SOV Clause
}

\section{Cyrine Nyomy*}

The University of Yaounde, Cameroon

Received: 17.11.2021 • Accepted: 05.01.2022 • Published: 03.03.2022 • Final Version: 05.03.2022

Abstract: Ever since Kayne (1994) which argues that the universal word order in a phrase is HeadComplement, many studies had proliferated in support of the LCA. Basically, at the level of the clause, many languages exhibit the SVO pattern but there are languages which display distorted word order among which the SOV. The Awing language has both orders and there are determined on the basis of the opposition positive versus negative clause. This paper examines the derivation of the Awing SOV structure and argues that this derivation involves basic movements such head and Amovements (Chomsky 1995) in addition to remnant and heavy pied-ping. It also proposes a reanalysis of the landing site of the raised remnant VP and argues (in contradiction to Nyomy (2019) who posits that the position of the raised VP is spec, AgrOP) that the raised remnant VP lands in spec, TopP (an IP-internal left periphery position as posited by Jayaseelan (2001)).

Keywords: Negation, remnant movement, Neg-raising, heavy pied-piping, scrambling Introduction.

\section{Introduction}

One of the purposes of linguistic analysis is to describe variation among languages and many studies in this domain try, with empirical corpus, to explain differences observed in clause constituents order. Basically, it is argued that the universal basic word is head-complement (Kayne 1994, Chomsky 1995, among others). One of the most observed word order distortion is that found between (S) VO and (S)OV languages. Typologically, most languages of the world fall within the VO surface order and languages that exhibit the OV one are usually said to derive from the VO pattern. Heine (1976) and Heine and Nurse (2008) goes further and argues that the VO pattern maps $71 \%$ of African languages. The consequence of head-argument order for syntax is quiet motivating and my interest to studying such aspect of the syntax is fundamentally based on of the grammar Awing, a Grassfield Bantu language which exhibits the VO as well as OV pattern: VO is the basic word expressed in positive statements (1a) while the OV order is exhibited as in negative sentences (1b):

1.

a. Fochi à pé’á nú nkǐə

Fochi SM TNS drink water

'Fochi drank water'

b. Fochi à pé’á kě nkì̀ nópô

Fochi SM TNS NEG water drink NEG 
'Fochi did not drink water'

This paper aims at providing a grained theory of the clause structure of Awing as exhibited in (1.b). I will argue that the SOV pattern is the consequence of head-agreement and the derivation of any negative clause involves the projection of IP-internal topic and focus phrases which stand as intermediate loci for various fronted elements. Let us first build the roadmap to our theory. In section 2, I will describe Awing basic clause constituents and word order. In section 3, I review various negations in Awing ${ }^{1}$ and distinguish between declarative, conditional, dubitative and imperative negation. Section 4 proposes the derivation of the SOV clause and reanalyze the AgrOP as TopP. Section 5 provides a critical analysis of the Awing COMP-system. It will establish the difference between raising and non-raising negation and posits that raised constituents occupy spec, TopP, in the IP-internal COMP-system. I conclude the paper in section 6.

\section{The basic word structure}

The basic clause structure is similar to that of any SVO language with a strict constituents ordering. Besides main syntactic categories like the noun and the verb, the clause is made up of elements of the TAM system. Tense in this language is subcategorized into past, present and future with approximate remoteness in the past and future. The table below is a summary of Awing tense markers.

2.

\begin{tabular}{|c|c|c|}
\hline $\mathrm{e}^{\text {Tens }}$ & Marker & Remoteness \\
\hline \multirow{4}{*}{ Past } & A floating low tone & $\begin{array}{l}\text { General past (P1): expresses an event that has } \\
\text { occurred before the moment of speech }\end{array}$ \\
\hline & Pé’é & $\begin{array}{l}\text { Immediate past (P2): expresses an event that } \\
\text { has occurred some minutes or hours ago }\end{array}$ \\
\hline & Kə̀/nə & $\begin{array}{l}\text { Also termed } \mathrm{P} 3 \text {, this past expresses events } \\
\text { that took place some days ago, a week or a } \\
\text { month }\end{array}$ \\
\hline & Nədá' & $\begin{array}{l}\text { Known as } \mathrm{P} 4 \text {, it is the most remote past in the } \\
\text { language. }\end{array}$ \\
\hline $\begin{array}{ll}\text { Prese } \\
\mathrm{nt}\end{array}$ & $\begin{array}{l}\text { No marker but uses } \\
\text { the progressive aspect }\end{array}$ & Decribes actions that are occurring now. \\
\hline \multirow{4}{*}{$\mathrm{e}^{\text {Futur }}$} & Y̌̃ & Also called F1, it marks the today future \\
\hline & Yǒ & $\begin{array}{l}\text { Termed F2, it expresses events that will occur } \\
\text { a couple of days of weeks }\end{array}$ \\
\hline & Lá’ & $\begin{array}{l}\text { F3 portrays events that may occur a couple of } \\
\text { months }\end{array}$ \\
\hline & Yǒlá’ & Known as F4, it is the most distant future \\
\hline
\end{tabular}

1 Awing is a Bantu Grassfield language spoken in the North West region of Cameroon and precisely in the Santa subdivision. The term Awing refers to the place, the people and the language itself though the natives called their language Mbíiwìỳ̀. As many Cameroonian languages, Awing is not taught is not used as mean of education. The language has a sketch of phonology (Azise 1993), an Awing-English dictionary (Alomorfor 2007) and few academic works among which Nyomy $(2012,2019,2020)$ and Fominyam (2012). 
Grammatically, Awing does not show a lot of markers that mark aspect since most of them are lexicalized. Nonetheless, few aspects, the progressive, the habitual, have grammaticalized morphemes. For all progressive aspects (past, present or future), the language uses tá and the habitual is introduced by $z \hat{a}$. These aspectual items immediately follow the tense marker. Illustrating tense and aspect division, consider the following:

3.

a. Fochi a nò zâ fá’̀̀ f̂̂ع

Fochi SM P3 HAB work here

'Fochi used to work here'

b. Fochi a tó fá’̀̀ fर̂ع

Fochi SM PROG work here

'Fochi is working here'

c. Fochi a pé'é n-gǐə méesânə

Fochi SM P1 Pf-come morning

'Fochi came this morning'

d- Fochi a yǒ yǐə ngwè'

Fochi SM F2 come tomorrow

'Fochi will come tomorrow'

Awing is a pro drop language and the agreement between the DP subject and the verb is marked by a subject marker which in many respect is a pronoun. This agreement item varies according to the subject number and in very few cases to noun class. For human, the agreement element is $a$ (singular) and po (plural). When the subject has non-human characteristics, agreement is coined by $\partial$ and $m$ s standing respectively for singular and plural. Returning to (3), the word ordering is fixed. In the I-domain, the position above the verb is occupied respectively by aspectual markers, preceded by tense and the agreement item. Objects and adjuncts are postverbal. One property of the verb is the ability to change its morphology with regard to some tenses. Though it may to proper to some verbs, especially those that have initial velar and the like sounds, verbs like yiz take a homorganic nasal $N$ in the past and present tense (as in 3.c) but not in the future (see 3.d). Some phonological changes occur: for example, when the velar sound [y] is preceded by the homorganic $N$, it becomes [-g]. To list few, other verbs with similar changes are ghená (y-gená) 'go', kíyá (y-kíná) ‘cry’ and $y \hat{\imath}$ o (ng-îa) 'eat'. To some extent, the forms in brackets can be referred to as the participle forms. This phenomenon is also observable in Màdûmbà, a genetic related language, where even non initial velar verbs take the homorganic nasal $N$ which can be translated as $[n],[\eta]$ or $[m]$ (see Pahane forthcoming).

In term of argument structure and transitivity, Awing distinguishes between one, two and three place arguments and intransitive and transitive predicate as illustrated below:

4.

a. Fochi a péé y-kínó

Fochi SM P1 N-cry 
'Fochi cried'

b. Fochi a nòn-nayá ndzǒo

Fochi SM P3 N-cookbeans

'Fochi cooked beans'

c. Fochi a yǐ f̌̌ ndzǒo abô Chefo

Fochi SM F1 give beans to Chefo

'Fochi will give some beans to Chefo'

d. Fochi a yǐ f̌̌ ndzǒo abô Chefo məm ndê

Fochi SM F1 give beans to Chefo in house

'Fochi will give some beans to Chefo in the house'

Giving that Awing is a SVO language, it respects the Larson's (1988) Thematic Hierarchy below:

5. Thematic hierarchy

AGENT > THEME > GOAL > OBLIQUES

Following (5) the order of arguments in transitive clauses is fixed. The direct object immediately follows the verb, followed by the indirect object and the adjunct always comes at the end of the sentence. Therefore, the predicate's internal constituency is the following: Verb - Direct Object Indirect Object - Adjunct. The conclusion to be drawn from what precedes is that, giving structures in (3-4), the order of clause constituent is rigid and must be in a manner that respects SVO linearilization. Since, the language under study lacks overt case morphology, the interpretation of the thematic role is related to the position of each argument with respect to the position of the inflected verb. Though arguments can undergo fronting for discourse reasons (topicalization, focalization, relativization, etc), the canonical word order of Awing is SVO. For more, visit Nyomy $(2012,2019)$. At the stage arrives at in the description of the basic word order, (4.c), for example will have the following syntactic bracketed labeling:

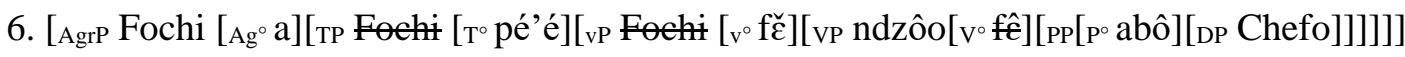

Regarding (3.a), the clause pattern is more elaborated that (6). An AspP can be projected below TP to host aspect markers. Concerning the mood system, the language lacks mood morphemes and the clause's mood is interpreted in relation to the overall meaning of the sentence. Therefore, (4a-b) are said to belong to realis mood (i.e. the speaker assumes the fact that his utterance is true and has been accomplished in the real world) while (4c. d) belong to the irrealis mood (i.e. there is no evidence that the event born by the utterance will take place in the real world). Since mood in Awing is related the overall interpretation of the clause, there can be a distinction between the declarative, conditional, dubitative and imperative mood. They will be largely discussed in section 3 . In the next section, I will discuss some type of negation. It will only concern those negations which fall in sentential or standard negation, negation which targets the whole sentence; in opposition to constituent negation which scopes over a sentence's constituent such as a VP, PP, DP, etc.

\section{Negation in Awing}

This section is twofold: the first part focus on negation in four moods and the second part distinguishes between raising and non-raising negation.

\subsection{Neg subcategorization}


Sentential negation in Awing has four subcategories and each of them belongs to a specific mood with a specific marker. To begin with, consider the following:

7. (Negation in the declarative mood (realis vs. irrealis))

a. Fochi a nòkěndzǒo n-nayá pô

Fochi SM P3 NEG beans N-cookNEG

'Fochi did not cook beans'

b. Fochi a yǐ kě ndzǒo abô Chefo f̌̌ pô

Fochi SM F1 NEG beans to Chefo give NEG

'Fochi will not give some beans to Chefo'

c. Fochi a yǐ kě ndzǒo abô Chefo məm ndê fě pô

Fochi SM F1 NEG beans to Chefo in house give NEG

'Fochi will not give some beans to Chefo in the house'

Comparing (7) to (4), there seems to be a clear distinction between positive and non-positive clauses (non-positive in this context qualifies sentences that have overt negative markers and which impact on the syntax of these sentences). We have argued, previously, that the basic word order in this language is SVO. In (7), the sentences exhibit SOV structures and what looks to be cause of this distortion is the presence of the discontinuous sentential negative marker ké...pô. This is the only the plausible conclusion because in previous examples and in the absence of the negative, the clauses show SVO word order. Thus in the negative declarative mood, negation is realized by two negative markers (see Nyomy 2019) and all postverbal complements must pass over the verb to occupy a position higher than $\mathrm{vP}$ and lower than $\mathrm{TP}^{2}$.. Structurally, no item can figure after the second negative marker $p \hat{o}$. Let us continue with negation in the conditional mood. In this perspective, consider the following:

8.

a. (Mbo) Mamoh a- chí'- yí- pô, gho fít $\angle \mathrm{m} \angle$

If Mamoh SM NEG come NEG tu tell me

'If Mamoh does not come, you inform me'

b. (Mbo) á chí' nà kólá- pô, gho shúm $\angle$ yá

If $3 \mathrm{sg}$ NEG meateat NEG you beat her/him

'If s/he does not eat her meat, beat her/him'

${ }^{2}$ Similar right to left (object) shift phenomenon in syntax had been early discussed by Ross (1967), Nkemnji (1995) and recently by Tamanji (2002), Hunter (2010) and (2012), among others. Though a cross-linguistic available property, right to left (object) shift phenomenon had been coined differently by various linguists and what could be agreed to also mark the difference in the description right-to-left shifting in syntax is the quantity of the shifted material. Thus, some right-to-left shifting might only involve the movement of a small unit the clause (a DP or a PP) while other will involve the movement of bigger clause's fragment (a vP, a TP, etc.) 
In the conditional mood, the if-item at the beginning of the sentence is not compulsory. Therefore, its absence will not mislead the interpretation of (8) as a conditional sentence. Thus, my position is that, as it is the case with the declarative mood, the interpretation of the condition also depends on the overall meaning of the sentence. In other words, the conditional meaning is dependent on the subornation relation that exists between the clauses. Though both clauses in (8.a), for example, belong to the same mood, negation only targets the clause which is the object of the condition. More evidence comes from the fact that the second clause does not fall in the scope of negation. Concerning the neg-marking, the particularity of the conditional mood is, from what we see in the data, the shape of the first discontinuous negative marker which completely differs from the one in the declarative mood. Comparing (8.a) and (8.b), it seems that there is not left dislocation in (8.a) as it is the case in (8.b). This is not the case and it is related to the intransitivity of the predicate $y \hat{\imath} \partial$ 'come'. But in section 4, our analysis will show that the predicate in (8.a) undergoes left dislocation. To continue, there are many similarities between negation in the declarative and the conditional mood as far as the position of negative markers and postverbal complements are concerned: (i) in the negative conditional as well as in the negative declarative mood, all postverbal complements objects and adjuncts - raise to a position higher that $\mathrm{vP}$ and lower than TP and (ii) pô is always (apparently) the last constituent in the clause. The reason why pô is apparently at the clause final position will be discussed in section 4 .

The third negation subcategory in Awing is the one which is found in negative imperative constructions. Consider the following illustrations below:

9.

a. Félá píßá

go out

'Go out'

b. Ko fél $\angle$ píßó

NEG go out

'Do not go out'

c. *Kっ fél $\angle$ pí ${ }^{*}$ ó pô

NEG go out NEG

'Do not go out'

Awing exhibits true negative imperatives and surrogate imperatives. It follows from (9) that in negative imperative constructions, there is only one negative marker that is positioned at the clause initial. Also as indicated by (9.c), there is no complement left dislocation (if we consider pízá 'out' as the complement of fél' 'go'). In the same line of thoughts, pô is not tolerated in negative imperative. Looking at the behavior of the clauses in (7-8), one might correctly predict that the fronting of all postverbal elements is, in fact, the consequence of the presence of $p \hat{o}$. Following this path, a question that arises is why pô and not the other negative markers involve the fronting of all postverbal elements?

Finally, the fourth class of sentential negation is the one introduced by $m \hat{a}$ as illustrated below:

10 .

a. Mamoh a péé mă kwó məətá (*məətáná) 
Mamoh SM P1 NEG return market

'Mamoh has not retuned from the market'

b. Chefo a pé'e mă nunkà aywa'lə ghó ndumə tébə̄lā

Chefo SM P1 NEG put book Poss on table

'Chefo did not put your book on the table'

c. *Mamoh a- pé’é mă kwá məətá pô

Mamoh SM P1 NEG return market NEG

'Mamoh did not return from the market'

Though I term mă as a negative marker, it more looks a type mood marker. It expresses doubt, hesitation and uncertainty. When it is, this marker seems to intend an indirect question and the structure of the NP maətá 'market' behaves like the one used in interrogation. As a matter of evidence, almost all nouns in Awing have a long and short form and only the short one is used in interrogation. Although these facts seem to qualify mă mood marker, I will maintain it as a negative marker with modal interpretation. At this point of the study, we can notice that the four subtypes of sentential can also be subcategorized in two groups: raising negation vs. non-raising negation. In what precedes, we have analyzed Awing negation in four types and the description has allowed observing that negative constructions have two patterns: (i) the SOV word order. This structure is observable in the negative declarative and conditional mood and (ii) the SVO observed in the dubitative and imperative mood. The questions which directly follow are: (a) what is the status of the negative marker in raising vs. non-raising negation? (b) what triggers the movement in raising negation? (c) what is the position of the fronted postverbal complements? (d) how many escape hatches are there above vP and below TP that can host the moved postverbal constituents? Answers to these questions will be provided below.

\section{Scrambling ${ }^{3}$ and the SOV labeling}

In previous sections, we have shown that the basic word order in Awing is SVO. But in what is worth to be called negative clauses (in opposition to positive statements), the SVO turns into SOV; thus pushing the language to belong to both SVO and SOV languages. In this section, I try to answer the questions under (a-d) and propose a clause structure of Awing which differs from that of Nyomy (2019). Now, consider the following to be the strict sample ordering of the VP domain:

\section{Awing VP domain}

a. V DO IO Adjunct

b. V DO IO Time Place

c. V DO IO Place Time

d*. V IO DO Adjunct

e*. V Adjunct DO IO

${ }^{3}$ If scrambling can be referred to as a process which allows to derive non-canonical word order, it can involve long or short distance movement targeting either an A or A' constituent (see Maha jan (1990, 1994). Following this author, A-scrambling is movement to an IP (AgrS, T, AgrO) SPEC (L-related) position: [IP NPj $[\mathrm{I}, \ldots . . \mathrm{tj} \cdots . .$.$] ] while A' -scrambling is adjunction (non-L-related position): [IP NPj$ $[\mathrm{IP} \cdots . . . \mathrm{tj} \cdots . .]$.$] (see Elena Anagnostopoulou and Danny Fox 2007)$ 
(11) is an illustration that in the language, in transitive predicate, the direct object (DO) always dominates the indirect object (IO) and adjuncts follow all internal arguments. If the order of internal argument is not interchangeable, the order of adjuncts (at least as far as the place and time adjuncts) is not limited by any constraints. Also, (11) is the basic clause constituents in non-negative sentences i.e. clauses lacking overt morphological negation's markers. To continue, consider the following constructions:

12 .

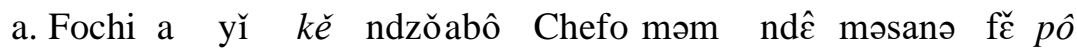

Fochi SM F1 NEG beans to Chefo in house morning give NEG

'Fochi will not give some beans to Chefo in the house'

b. Fochi a y̌̃ kě ndzǒabô Chefo məsanə məm ndê f̌̌ pô

Fochi SM F1 NEG beans to Chefo morning in house give NEG

'Fochi will not give some beans to Chefo in the house'

13.

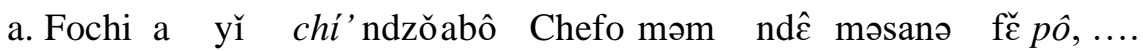

Fochi SM F1 NEG beans to Chefo in house morning give NEG

'If Fochi will not give some beans to Chefo in the house,...'

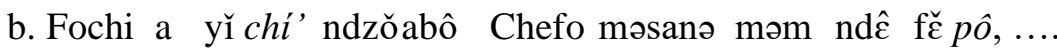

Fochi SM F1 NEG beans to Chefo morning in house give NEG

'If Fochi will not give some beans to Chefo in the house, ....'

Looking at (12-13), it is the presence of the discontinuous negative markers, kě...pô in (12) and chi'...pô in (13) that provokes the displacement of all postverbal complements at the left of the verb. More refine, by what mechanism all VP complement leave their in-situ positions. The answer of this question necessarily brings us back to the questions (a-d) designed above. Therefore, and since only these two discontinuous negative markers trigger neg-raising, the first path is to find out their syntactic nature. For the nature of the negative markers involve in the discontinuous sequence, also called bipartite negation, Nyomy (2019) claims that, following Merchant (2001) and Zeijlstra (2004), $k e \check{~ a n d ~ c h i ' ~ a r e ~ n e g a t i v e ~ a d v e r b s ~ a d j o i n ~ t o ~ s p e c, ~ V P . ~ A c c o r d i n g l y, ~ p o ̂ ~ i s ~ t h e ~ h e a d ~ o f ~ N e g P . ~}$ Syntactically, pô is higher in the derivation than either ké or $c h i ́$ '. In other terms, the unmarked structure of the discontinuous negative markers in (12-13) is that shown in (14).

14. [TP...NegP....Neg pô...vP kě/chí 'v...]

The structure in (14) is the word ordering in neg-raising constructions. We had indicated above that the language distinguishes between clauses like those in (12-13) where all postverbal complements are located in a position that immediately c-commands VP and those in (9-10) the same postverbal complements (by virtue of being internal arguments of adjuncts) are in the c-commanding domain of VP. It will follow that the negative markers in (12-13) are systematically and syntactically different from their counterparts in (9-10). On this base, Nyomy (2019) argues that mă is weak 
negative head which is unable to trigger movement. He also argues that $k o$, the imperative negative marker is a negative adverb but does not involve the same kind of movement that ké does. In other terms, negative imperative constructions involve the movement of $\mathrm{V}$ to $\mathrm{Neg}$ and in a spec-head agreement relationship, spec, VP raises to spec, $\mathrm{NegP}$ as illustrated below (since imperatives are agentless and timeless constructions, we only represent the structure that allows the interpretation of the negative features, $\mathrm{NegP}$ ):

15 .

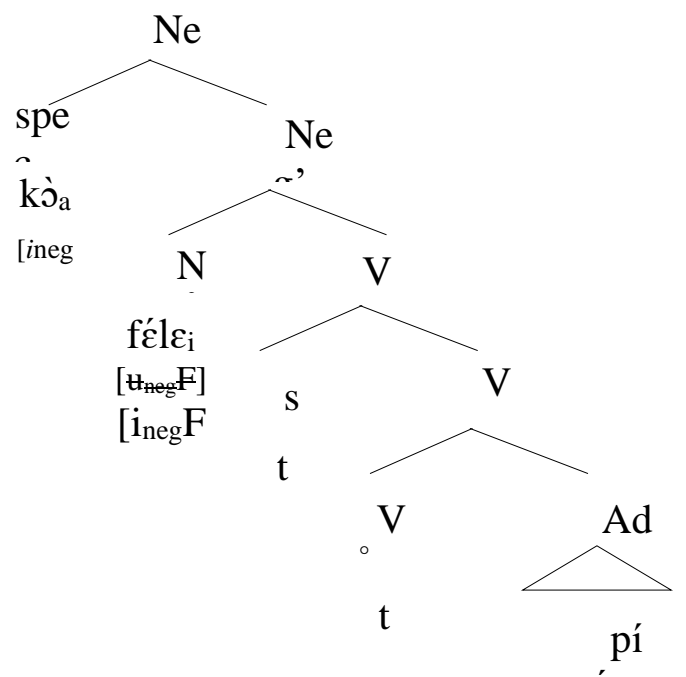

The claim is that negative imperative and mă-constructions do not involve leftward movement of postverbal complements, evidence that all Awing negative markers (those that are in the inflectional domain) do not have the same features. Now, let us return to question (b), i.e. what triggers movement in raising negation? Put differently, what feature(s) of which neg-marker trigger(s) VP-complements to a position before V? Before we provide an answer to (b), let us do some corrections that have been kept aside till now. From what precedes, one might believe that movement in neg-raising constructions does not concern the verb and that only the complements move. On the one hand, there is verb movement followed by complements movement, and the movement of vP to an escaped hatch above $p \hat{o}$, on the other hand. Standard negative clauses are evidence that, structurally, $p \hat{o}$, is at the clause final position though this position is only apparent as pô is the head of NegP which syntactically dominates vP. Returning to (b), let us assume that the negative adverb kélchi' is drawn from the lexicon and enters the derivation with positive negative features $[+n \mathrm{~F}]$. On the other hand, pô is embedded with $[-n \mathrm{~F}]$ which must undergoes checking before spellout. In its c-commanding domain, the only constituent with matching interpretable features is the adverb kélchi' adjoined to spec, VP. Thus, in an agreement symmetry following Chomsky $(1995,2008)$ the constituent merged in spec, VP undergoes leftward dislocation to spec, NegP. The puzzle here is that this movement does not imply spec, VP but the entire vP. The question that immediately follows is how one derives the SOV involves in (12-13). Another related question is the previous (c) which in turn questions the escaped hatch of constituents of moved vP. To continue, let us reconsider (12.a) repeated below in (17) and (15) which is its positive counterpart:

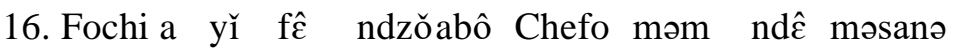
Fochi SM F1 give beans to Chefo in house morning

'Fochi will give some beans to Chefo in the house' 


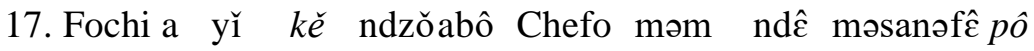
Fochi SM F1 NEG beans to Chefo in house morning give NEG

'Fochi will not give some beans to Chefo in the house'

First of all, the positive clause in (16) respects one the variants in (11.a-c) where the order of the VP interments constituents is DO, IO and Adjunct(s). But in (17), the word order is reversed. If we keep aside negative markers, the VP internal constituents order is the complete opposite of (16), i.e. DO IO Adjunct(s) V. Thus, both word orderings in Awing have the structure in (18):

18. Positive vs. negative clause word order

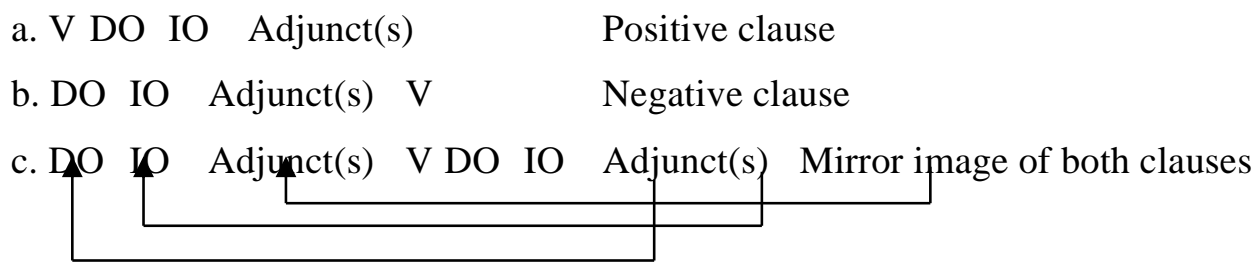

A number of facts are observable in (18): (i) the closest argument to $\mathrm{V}$ in (18.a) becomes most distant in the (18.b) and (ii) nothing in (18.c) seems to show that the verb undergoes any movement. Now, let us return to question (c) and explain the derivation of the SOV pattern in (17) and revise the position of the escaped hatch for the moved constituents. In a previous study by Nyomy (2019), the author argues that the escaped position for the moved items is spec, AgrOP. In this analysis, I argue against this position and posit that the escaped of the moved items is the IP-internal-COMP system translated following Rizzi (1997) and subsequent works. These positions include TopP and FocP. How do vP constituents escape at this positions and for which reason?

The reason to use internal TopP and FocP as escaped hatches for moved items in the vP domain rests on the following facts. Negative statements are usually counterparts for positive statements and as such, the negated information is a repetition of old information. Thus, (16) is said to be the new information and therefore can receive neutral focus reading. On the contrary, (17) is the negation of an information that already exists in the discourse context, thus an old information. Taking on these bases, the escaped hatch of the VP internal complements is TopP. Let us also recall that many movements are involved in the derivation (16) that leads to (17): head movement, remnant movement, A-movement and heavy pied-ping. Let us develop on these movements. To do so, reconsider the following clause (17) repeated in (19):

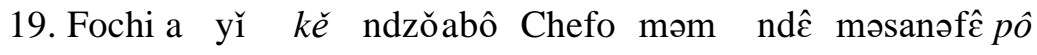

Fochi SM F1 NEG beans to Chefo in house morning give NEG

'Fochi will not give some beans to Chefo in the house'

The first movement involves in the derivation of the Awing SOV word order is the head movement of $\mathrm{V}$ to v. As reminder, the negative, as we have argued above, is base-generated in spec, VP and dominates $\mathrm{V}$ and its complements. Once head movement of $\mathrm{V}$ to $\mathrm{v}$ has applied, the order of the 
remaining constituents in the VP domain is the negative adverb preceding all verbal complements as shown in the bracketed structure below:

20. [vp Fochi [v f̂́ [vp kě [v f̂́ [ndzǒ abô Chefo məm ndê məsanə]]]]]

At this point, the first movement of the negative adverb ké consists of pied-piping along all the remaining constituents of VP to a position above $\mathrm{vP}$ generating the word order where the verb is at the clause final position. This said position is spec, TopP as illustrated below:

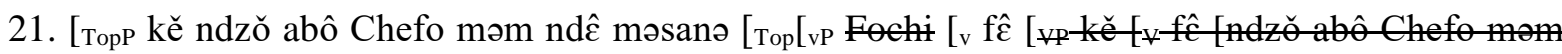
ndê masañ]]]]]]]

What to do next is to the extraction of TopP to spec, NegP to check the uninterpretable negative feature of the NegP head pô. In other terms, this extraction implies the movement of (21) to spec, NegP resulting in a construction where $p o ̂$ is definitely at the clause final position, thus the derivation of SOV as shown in (22):

22. [NegP kě ndzǒ abô Chefo məm ndê məsanə fî $\left[\mathrm{Neg}^{\circ}\right.$ pô[ [opp kě ndzǒ abô Chefo məm ndê məsanə

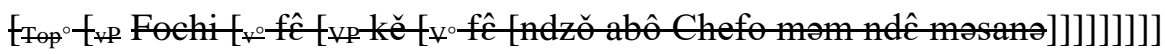

At this point, we have explained the derivation of the Awing SOV. The complete derivation will project above NegP, TP and AgrSP whose heads will host the tense marker as the SM, respectively. Finally, the subject will, after extraction from spec, vP, merge at spec, AgrSP. Now, let us return to (18) to discuss more. The mirror image seems to indicate that constituents move individually. If that is the case, then, it means theoretically that there are iterate TopPs above vP (Malayalam has such iterative TopPs above FocP (see Jayaseelan $2001^{4}$ )). But do we really have multiple escaped hatches above $\mathrm{vP}$ in Awing SOV clauses? The answer to this question has already been provided. The SOV structure cannot be derived by a phrase to phrase movement where the constituents in the VP move individually to different position above vP. If we do so, then we will have to motivate such movements and for the time being, there nothing more than the valuation of the uninterpretable negative feature of the NegP head pô. Working against AgrOP in favor of TopP is strictly based on interpretation of VP as old information and not on syntactic/morphological variants. Though they undergo movement, all the postverbal complements keep their canonical order. For these reasons, I claim that there is only one escaped hatch, TopP, above vP in Awing SOV string and that there is no phrase to phrase movement but one remnant movement of VP to spec, TopP followed by movement of TopP to spec, NegP. To conclude this section, Awing is an SVO language and its SOV derived through multiple movement involving (i) the extraction of spec, vP to spec, AgrSP; (ii) the movement of $\mathrm{V}$ to $\mathrm{v}$; (iii) the remnant movement of VP to spec, TopP and lastly (iv) the heavy pied-piping of

${ }^{4}$ Here is Jayaseelan (2001)'s full abstract stating the motivation of postulating internal TopP and FocP between TP and vP: It is shown that postulating a Focus Phrase above vP enables us to explain such diverse phenomena as the Malayalam question word's position contiguous to $V$, the 'remnant' in English pseudogapping, the clause-final 'floated' focus marker in English, and the position of the 'cleft focus' in English and Malayalam clefts. Assuming a Kaynean view of the underlying structure of the SOV languages, we argue that the 'canonical' positions to which the verb's internal arguments are move in these languages are above this Focus Phrase. Postulating an iterable Topic Phrase above Focus Phrase (and above the 'canonical' positions in SOV languages) enables us to account for the definiteness/specificity constraints on clause-internal scrambling in Malayalam, German and Dutch, and on object shift in Scandinavian. Finally, it is shown that all the functions attributed to an 'outer' Spec position of $v P$ are better fulfilled by the Topic/Focus positions above $v P$ that we postulated. 
TopP to spec, NegP ${ }^{5}$. In the next section, I will develop on some other clause distortion related to negation. These distortions mainly concern interrogation and predicate focusing.

\section{Negation and information structure}

In the previous sections, we have seen how negation impacts the clause structure in Awing. Fundamentally, we have argued that the language is SVO but also exhibits SOV in standard negative sentences. In the next lines, I will show and try to explain how negation interacts with information structure. I focus on interrogative and predicate focus constructions.

\subsection{Negation and interrogation}

In Awing interrogatives, the question words can remain in-situ or be fronted. When they are fronted, these question words undergo relativization. To continue, let us indicate that in the course of this paper, question words include all wh-elements which quiet differ from question morphemes (QM) which are pure functional items including, for example, vowel lengthening in echo questions and éé in yes-no questions as illustrated below:

23.

a. Ngwe à pé'é jí məjî̀ á

Ngwe SM P1 eat food QM

'Did Ngwe eat the food?'

b. Ngwe à péé ngénó mátáá

Ngwe SM P1 go market QM

'Did Ngwe go to the market?'

c. Ngwe à pé’é jí lá akā

Ngwe SM P1 eat FOC what

'What did Ngwe eat?'

d. Lá akā pá’̄ô Ngwe à pé’é jí *(záorá)

FOC whatCOMP Ngwe SM P1 eat it

'What did Ngwe eat?'

The symbol * indicates that, in this specific environment, the verb cannot be stranded neither in echo and yes-no questions nor in $w h$-questions. As questions in (23a-b) somehow repeat the declarative statement, the clause right edge is occupied by a question morpheme and it is usually identical to the final vowel of the last word in the clause. When arguments move as in (23c-d), they also allow NP retention. Let us keep this aside and return to negation. In standard or sentential negative yes-no

${ }^{5}$ Let us note that various movements involve in the derivation of the Awing clause will occur in accordance with Chomsky (2008)' phase approach. I adopt the phase-based approach because it helps solving some limit in Nyomy (2019). Thus, since the Awing SOV pattern involves multiple search, I following the phase-based approach which better account for various targeted landing sites. Following this approach, the movements numbered from (i) to (iv) occur either independently or randomly. 
questions, for example, the structure of the clause is different from that of sentential negative declaratives. Consider the following:

24.

a. Ngwe à pé'é kěməjî̀ jí á

Ngwe SM P1 NEG food eat QM

'Did Ngwe not eat the food?'

b. Ngwe à pé'é kěmátángéná á

Ngwe SM P1 NEG market goes QM

'Did Ngwe not go to the market?'

In negative declaratives, sentential negation is rendered by a bipartite marker made up of the negative adverb kě, base-generated in spec, VP, and later raised to in spec, NegP; and the Neg head pô. But in (24) which are negative yes-no question, only one element of the bipartite negative marker shows up. In other words, if the negative adverb ké can show up at the position where it normally surfaces in clauses such as (17-19) and the absence of does not marks the clause ungrammatical, if follows that the negative reading in (24) is not dependent of the Neg head pô. This also means that the negative adverb, alone, is sufficient to type (24) as a negative structure. Now, the question that arises is why pô is in (24) and it does lead to any ungrammaticality? I would argue that the absence is not fair and it due to the presence of the question marker. In fact, the question marker and the Neg head $p \hat{o}$ are in complementary distribution; and since the negative adverb kě has strong $[+n \mathrm{~F}]$ and therefore is able to type the sentence as negative (rendering by that same fact $p \hat{o}$ redundant), the question marker takes over the Neg head (see Nyomy 2019 for more details). Another question at this point is to find out whether (24) projects a NegP or not. I will return to this question later on. We have argued above that I the absence of $p \hat{o}$ is justified by the presence of the question marker and because both are complementary distribution, the question takes over the Neg head. This is typical to yes-no and echo questions. The picture is quite different with questions involving $w h$-items. Let us consider a series of $w h$-questions and observe the behavior of the $p \hat{o}$. In this vein, consider the following:

25 .

a. Ngwe à pé'é kělá ak̄̄ nópô

Ngwe SM P1 NEG FOC whatdrink NEG

'What did Ngwe not drink?'

b. Lá akā pá’̄̄ Ngwe à péé kěnópô

FOC whatCOMP Ngwe SM P1 NEG drink NEG

'What did Ngwe not drink?'

26.

a. Fochi à péé kělá wā fón pô

Fochi SMP1 NEG FOC who call NEG

'Who did Fochi not call?' 
b. Lá wà pá'̄ Fochi à péé kěyáa fón pô

FOC who COMP Fochi SM P1 NEG him/her call NEG

'Who did Fochi not call?'

27.

a. Fochi à pé'é kěNgwe fón lá əfó

Fochi SMP1 NEG who call FOC where

'Where did Fochi not call Ngwe?'

b. Lá əfó pá’ā Fochi à pé'é kěNgwe fón pô

FOC where COMP Fochi SM P1 NEG Ngwe call NEG

'Where did Fochi not call Ngwe?'

28.

a. Fochi à péé kěNgwe fón lá ágháká

Fochi SM P1 NEG Ngwe call FOC when

'When did Fochi not call Ngwe?'

b. Lá ágháká pá’̄ Fochi à pé'é kěNgwe fón pô

FOC when COMP Fochi SM P1 NEG Ngwe call NEG

'When did Fochi not call Ngwe?'

29.

a. Fochi à pé'é kěNgwe fón lá ntéká

Fochi SM P1 NEG Ngwe call FOC why

'Why did Fochi not call Ngwe?'

b. Lá ntéká pá’ā Fochi à pé'é kěNgwe fón pô

FOC why COMP Fochi SM P1 NEG Ngwe call NEG

'Why did Fochi not call Ngwe?'

In negative questions involving $w h$-arguments like in (25-26), pô is compulsory no matter the position of the said arguments. But when questioning concerns adjuncts (27-29), the presence pô is only compulsory when there is movement of the wh-adjunct. Therefore, it seems clear that there exists an asymmetry among the $w h$-items. In other terms, based on (25-29), wh-arguments and $w h$ adjuncts share different syntactic properties in negative interrogatives. Normally, one could expect movement of ké in the (a) examples in (27-29) to shift all the elements in the VP domain to the left of the verb as it is the case in any construction involving sentential negation. Following this observation, I will postulate that there is a weak cross-over when adjuncts are concerned, that is there is a property of the ké to obligatory license $w h$-arguments and not $w h$-adjuncts. This property can be formulated as following: 
30.

Any daughter node dominated by VP is under the scope of the negative adverb generated in spec, VP and must be pied-piped alongside with kè. Adjuncts are excluded in this scope-relation.

Excluding adjuncts from (30) also exclude them as mandatory objects of the verb. Though amendments can be brought to (30), let us take it as satisfactory to resolve the problem of the weak cross-over of adjuncts. Another preoccupation is why adjuncts in negative interrogative constructions involving $w h$-movement behave like $w h$-arguments in negative interrogatives as seen in the (b) counterparts in (27-29). Recall that we have indicated above that the verb cannot be stranded. Thus, we have also seen that the right edge of (at least) the negative questions involve two kinds of elements: (i) the QM in yes-no or echo questions and (ii) the Neg head pô. Since both items are in complementary distribution, they are mutually exclusive. Now, when adjuncts move against (30), pô fills the gap allowed by their extraction. Other evidence which shows that cannot be stranded follows from the examples below:

31.

a. Fochi à pé'é ngénə máətéená

Fochi SM P1 gomarket

'Fochi went to the markert'

b. Fochi à péé ngénə ófó

Fochi SM P1 gowhere

'Where did Fochi go to'

c. Lãófó Fochi à pé’é ngénə *(wá)

Foc where Fochi SM P1 gothere

'Where did Fochi go to'

(31) is evidence that the verb cannot be stranded in question. The extraction site must be occupied by a question marker or the Neg head $p \hat{o}$. Now, there is a serious worry which arises and needs more attention. The fact that the verb cannot be stranded seems to clearly demonstrate that the postverbal position needs an obligatory complement. If this is correct, then, why in the case of some adjuncts we don't have lexical of functional correspondence. When an argument moves, it usually allows an overt copy (termed as a resumptive pronoun) at its internally merging position as in (23.d). Though some adjuncts also have this characteristic (see 31.c), not all of them have the potential to merge insitu an overt copy. To answer the preoccupation stated above, I would like to indicate, in fact, that neither the QM nor pô are synonymous (neither by nature nor by function) to the moved adjuncts. My development is that, just like in incomplete VP, there is a post VP-pseudogapping in some fronted adjunct constructions in Awing and a constraint that allows spell-out of the Neg head in such constructions as shown by the strikethrough in order to avoid verb stranding.

32 .

a. Láəfó pá’ə Fochi à pé'é kěNgwe fón lá-əfé pô

FOC where COMP Fochi SM P1 NEG Ngwe call FOC where NEG

'Where did Fochi not call Ngwe?' 
b. Lá ágháká pá’ə Fochi à pé'ékě Ngwe fón láágháké pô

FOC when COMP Fochi SM P1 NEG Ngwe call FOC when NEG

'When did Fochi not call Ngwe?'

c. Lá ntéká pá’ə Fochi à pé'é kěNgwe fón lántékó pô

FOC why COMP Fochi SM P1 NEG Ngwe call FOC why NEG

'Why did Fochi not call Ngwe?'

I will stop here for the interaction between negation and interrogatives because the richness of the phenomenon is beyond the scope of this single work. Many questions remain to be answer and I myself would not have answers to all of them. In the next section, I will talk about some intricacies in predicate focusing in relation to negation.

5.2. Negation and predicate focus constructions

Predicate focusing in Awing as in some Bantu Grassfield languages shows some interesting results. In focus predicate constructions, the verb undergoes doubling. Consider the following as shown below:

33.

a. Fochi à pé'é nónkǐə lá no-nă

Fochi SM P1 drink water FOCdrink-INF

'Fochi DRANK water'

b. Fochi a yı̌ ghenə lá ghenə-(nว̆)

Fochi SM F1 goFOCgo-INF

'Fochi will GO'

c. Ngwe a foy Fochi lá fon-nă

Ngwe SM call Fochi FOCcall-INF

'Ngwe CALLED Fochi'

In (33), verb focalization is done via verb doubling and from the data, a number of phenomena can be observed. Though there is verb duplication, to begin with, the final copy of the latter is preceded by the FOC marker la as it is the case with any focus constituent in Awing. In addition, the verb's copy which shows up clause finally is in the infinitive form. In other words, for both verbs, only one copy is inflected for tense and felled in the domain of the tense marker. Lastly in transitive constructions, the internal argument(s) immediately follow(s) the unfocused verb, thus allowing the focus verb objectless. In this paper, what is also interesting is to find out under which conditions (context) (33) is generated because (33) is not a normal construction. Focused constructions are usually generated to for full specific purposes. If $w h$-focusing necessitates the questioning of either arguments or adjuncts (non-verbal constituents), predicate focusing carries on the action of the verb 
itself. That is (33), for example, is a suitable answer for any question which targets the contents of the verb. Thus, the question that helps to generate (33) will question the predicate and not the $w h$ items. Such a question will substitute the predicate by ghela' 'do' as follow:

34.

Speaker A: Fochi à péé ngedlá akə nánkǐə

Fochi SM P1 doFOC whatwith water

Speaker B: Fochi à pé'é nónkǐo lá no-nă

Fochi SM P1 drink water FOCdrink-INF

35 .

Speaker A: Fochi a yǔngedló akə

Fochi SM F1 doFOC what

Speaker B: Fochi a yǐ ghenə ló ghenə-(nə̌)

Fochi SM F1 goFOCgo-INF

In (34-35), the sentence is questioned by the nged-insertion and the contents of the predicate is therefore analyzed as the complement (object) of the said predicate. What I mean here is that in constructions like those in (33), the inflected original copy functions as the main verb and the focused copy as its argument complement. This could, in part, explain the presence of the focused $w h$-item lá aka. Another explanation of the focused verb functioning as a DP comes from its capacity to be preceded by the focus marker (however, only DPs/adjuncts take the focus marker) and the presence of the infinitive marker. In many languages, verbs can function like nouns and Awing doesn't make an exception. In fact, in the word processing, Awing derives a lot of nouns from verbs by prefixing a nominalizer to the infinitive verb (see Nyomy 2012). Thus, Awing verbs typically function as predicate object as follow below:

36.

a. May yǒghená mə-nyī-nə

I F2 goNOM-walk-INF

(Lit: I will go to walk)

'I will have a journey'

b. Mạ kón mə-kīy-nə

I like Nom-cry-INF

(Lit: I like to cry)

'I like cries'

c. mə-nyī-nə nəto’’́ kěpon’́ pô

NOM-walk-INF night NEG be.nice NEG

(Lit: To walk tonight is not good)

'Walking at night is not fine' 
The nominalization processing in (36) is also applicable to previous focused predicate. Thus (33) also has the following structure in (37). Considering the focused verb to be a noun/DP, the Awing nominalized infinitive verb will have the form of the English cleft verb-ING.

37.

a. Fochi à pé'é nónkǐo lá mə

Fochi SM P1 drink water FOCNOM-drink-INF

'It is DRINKING the water that Fochi did'

b. Fochi a yǐ ghenə lá mə-ghenə-(nว̆)

Fochi SM F1 goFOCNOM-go-INF

'It is GOING that Fochi did'

c. Ngwe a fon Fochi lá mə-fon-nว̆

Ngwe SM call Fochi FOCNOM-call-INF

'It is CALLING Ngwe that Fochi will do'

In what precedes, we have shown that the focused verb functions like the main verb object complement (with prominence for intransitive verbs like ghenə 'go') since it has all the noun properties (see 36). Now, let us see what when the focused predicate is negated. Consider the following set of examples (also see Nyomy 2019: chap 9):

38.

a. Fochi à péé kěnkǐə lá no-nă nópô

Fochi SM P1 NEG water FOCdrink-INF drink NEG

'Fochi did not DRINK water'

b. Ngwe a kěFochi lá fon-nă fon pô

Ngwe SM NEG Fochi FOCcall-INF call NEG

'Ngwe did not CALL Fochi'

The data in (38) behave similarly as the data which have been discussed above concerning negraising in standard negation. Keep aside the fact the verb undergoes doubling, the raising of the negative adverb kě pied-pipes the direct object and the focused verb giving the sentence the same SOV string. As a remainder, we have argued in previous sections that, in SOV pattern, the moved constituents consisting of arguments and adjuncts land in spec, TopP. Considering these constituents to be old information, there was no need to project a FocP either above or below TopP. Now, the question is should we consider the focused verb to be in the scope of the negative adverb or not. Put differently, does the data in (38) fall in the scope of the constraint stated in (30)? At a first glance, it is clear that the negative adverb also took along the focused verb. But at this point, the extraction is similar to what happens in (22), for example. I argue that, at the extraction site, there are indefinite copies of the same verb which move accordingly (see Nyomy (2019)). Thus, which movement first

\footnotetext{
${ }^{6}$ In speech, speakers have decided for stylistic reason not to pronounce the nominalizer at PF though it is spelled out.
} 
takes place; I posit that a copy of the verb moves to FocP, below vP, followed by the movement of VP to spec, TopP, higher than FocP (this explanation does no longer take into considerations minor extractions such V to v). Now, why the verb's copy in FocP is phonetically different from the copy in VP? In FocP, the verb carries infinitive affixes while the in-situ copy lacks these features and why is it this way? The reason is that spellout cannot produce two instantiations of the same item which are visible in PF and LF. Then to differentiate the focused verb to the main verb, the Awing language has a parameter which allows carrying infinitive markers. Given that the infinitive and the inflected verb had discriminated forms, both are spelled out are visible at PF and LF. In the footnote 6, we have indicated that, for stylistic reason, the Awing speaker has decided not to pronounce the nominalizer. Another reason is to clear mark the boundary between when a verbal form is used as a noun or as a verb. This second argument clearly distinguishes (38) to (39) where the focused verbs have shift variants. If in (38) the focused item is clearly defined as a verb, in (39), it is the contrary. It looks more like a DP/noun than a verb and this difference is due to the absence vs. the presence of the NOM(inalizer). Consider the following in (39):

39.

a. Ngwe a péé kělá mə-kin-nǒ kíná pô

Ngwe SM P1 NEG FOCNOM-cry-INF cry NEG

'She did not do the CRYING'

b. Fochi a yǐ kělā mə-ghยnə-(nว̆) ghénə pô

Fochi SM F1 NEG FOCNOM-go-INF goNEG

'Fochi will not do the GOING'

c. Mạ kělá mə-nyinâ nyinâ pô

I NEG FOCNom-cry-INF walkNEG

'I did not do the WALKING'

Now, watch the translation given to what seem to the focused verbal form. In (39), the focused verbal form is not considered as a verb but instead as a deverbative (that is a noun derived from a verb (see Kouankem (2012))). Following the nominal reading of the focused item in (39.a-c), I will refer to the latter as a nominal rather than a verb. As such, (39) is simply a typical instance of lower focusVP internal focus- which has undergone movement through the raising of the negative adverb as it is the case in any SOV construction involving standard negation. With this in mind, (39) is excluded as a predicate focused construction. To continue, Nyomy (2019) considers (40) as instantiations of three copies of the verb:

40.

a. Ngwe a péé kěkíná lá mə-kin-nǒ kíná pô

Ngwe SM P1 NEG cry FOCNOM-cry-INF cry NEG

'Ngwe did not CRY'

b. Fochi a yǐ kěghénə ló mə-ghenə-(nว̌) ghénə pô 
Fochi SM F1 NEG goFOCNOM-go-INF goNEG

'Fochi will not go'

c. Mạ kěnyinâ lá nyi-nô mə-nyinâ pô

I NEG walkFOCcry-INF NOM-walk NEG

'I did not walk'

(39) has been excluded from focused constructions because the verbal form which is focused has been qualified as a noun and merged as the internal argument before undergoing external merge. This also implies that in constructions of the types in (39), there is only one verb. With this in mind, (40) is likely to be focused constructions than any others, having two copies of the verb. Contrary to Nyomy (2019), I would not agree that there are three copies of the verb in (40.a-c) but two copies with an internal argument having a verbal shape. What looks intriguing in (40) is the position of the internal argument in relation to the negative adverb. We have shown, with a lot of evidence, that when the negative adverb moves; it takes alongside all the items in the VP domain in order to derive the SOV of Awing negative clauses. But (40) seems to go against this rule. If so, how do we characterize the structure in (40)? From this point, I will no longer coin lá as the FOC marker for the simple reason that Fominyam and Simik (2017) consider the said marker as an exhaustive focus marker. Whatever the lá item is called to be-Emphatic marker (Fominyam (2012)) - or Exhaustive marker (Fominyam and Simik (2017)) - the purpose is its implication in the derivation of the focused constructions in Awing. I would also like to indicate that my objective is not to propose a finegrained derivation of constructions like those in (40) but more to describe the data as they appear. Therefore, adopting the ExhP (Fominyam and Simik (2017)) over the EmpP (Fominyam (2012)) is not of greater change in our derivation of (40).

\section{Conclusion}

In this analysis proposed in this paper, the structure of the negative clause in Awing shows challenges to the minimalist view proposed in Chomsky (1995) and subsequent works. In a previous work on the language (Nyomy 2019), the raised negative remnant VP had been said to occupy the specifier of AgrOP and the through a heavy pied-piping movement, AgrOP is raised to spec, NegP. This results in the derivation od the SOV word order. Following studies proposed in Jayaseelan (2001) in which he argues that there is a left periphery incorporated between TP and vP, we reanalyze the AgrOP position as IP-internal Top and Foc positions. This new approach better suits and explains the various movement cycles involved in the derivation of SOV patterns in Awing.

\section{References}

[1] ALOMOFOR, C. (2007). Zé’ má fóy ná kí ywa lá Mbút́wiyə. Cameroon Association for Bible Translation and Literacy (CABTAL). Yaounde

[2] ANAgnOStOpOUlOU, E. and FOX, D. (2007). Course materials for 24.952 Advanced Syntax, Spring 2007. MIT Open Course Ware (http://ocw.mit.edu/), Massachusetts Institute of Technology. Downloaded on [2021-11-1].

[3] AZIESHE, G. (1994). Phonologie structurale du awing. Mémoire de DIPES II, Université de Yaoundé I, Cameroon.

[4] CHOMSKY, N. (1995). The minimalist program. Cambridge, MA: The MIT Press.

[5] FOMINYAM, H. (2012). Toward the fine structure of the Awing left periphery. MA dissertation, University of Yaounde 1, Cameroon. 
[6] FOMINYAM, H. and SIMIK, R. (2017). The morphosyntax of exhaustive focus: A view from Awing. In Natural Language \& Linguistic Theory.

[7] HAEGEMAN, L. (1995). The syntax of negation. Cambridge: Cambridge University Press.

[8] HEINE, B. (1976). A Typology of African Languages: Based on the Order of Meaningful Elements. Berlin: Dietrich Reimer.

[9] HEINE, B., and NURSE, D. (2008). A linguistic geography of Africa. Cambridge : Cambridge University Press.

[10] HUNTER, T. (2010). Relating Movement and Adjunction in Syntax and Semantics. PhD thesis, University of Maryland.

[11] HUNTER, T. (2012). A Constraint on Remnant Movement. In Anna Maria Di Sciullo (Ed.). Towards a Biolinguistic Understanding of Grammar: Essays on interfaces. Pp 31-56.

[12] JAYASEELAN, K. A. (2001). IP-internal topic and focus phrases. In Studia Linguistica, 55(1). Pp 39-75

[13] KOUANKEM, C. (2012). The Syntax of the Màdûmbà determiner Phrase. Ph. D. thesis, the University of Yaoundé I/ Cameroon.

[14] LARSON, R. (1988a). 'On the double object constructions'. Linguistic Inquiry 19. Pp 335-391.

[15] MAHAJAN, A. K. (1990b). LF Conditions on Negative Polarity Licensing. Lingua, 80:4. Pp 333-348.

[16] MAHAJAN, A. K. (1994). Toward a Unified Theory of Scrambling. Nn N. Corver and H. C. van Riemsdijk, (Eds.), Studies on Scrambling: Movement and Non-movement approaches to Free Word-Order Phenomena, Mouton de Gruyter, Berlin. Pp 301-330.

[17] MERCHANT, J. (2001). Why no(t). Ms, University of Chicago.

[18] NKEMNJI, M. (1995). Heavy Pied-Piping in Nweh. Doctoral dissertation, UCLA.

[19] NYOMY, C. (2012). Quelques aspects de la grammaire de l'awing. MA, Université de Yaoundé I.

[20] NYOMY, C. (2020). Exploring negation in Awing. In Journal of Translation and Language Studies, 1(1), Pp 94-107

[21] PAHANE, N, A. L. (to appear). Serial verb constructions and the Mòdûmbà clause structure, Doctoral dissertation. University of Yaounde I

[22] RIZZI, L. (1997). 'The Fine Structure of the Left Periphery'. In Liliane Haegeman (Ed.). Elements of Grammar: Handbook of Generative Syntax. Pp 281-337. Dordrecht: Kluwer.

[23] ROSS, J. (1967). Constraints on variables in syntax. Ph.D. thesis, MIT.

[24] TAMANJI, N. P (2002). Negation, verb movement and word order in Bafut. Journal of West African Languages 29. 1. Pp 45-64.

[25] ZEIJLSTRA, H. (2004). Sentential Negation and Negative Concord, PhD thesis, University of Amsterdam. 